\title{
IDENTIFYING LICHEN-RICH AREAS IN NOVA SCOTIA
}

\author{
ROBERT CAMERON* \& DUNCAN M. BAYNE
}

Nova Scotia Department of Environment

Halifax, NS BON $2 \mathrm{HO}$

Shelburne, NS BOT 1 WO

Nova Scotia supports an exceptionally high diversity of lichen species. The province's geographic position in the North Atlantic, and high coastline length in relation to area ratio, ensure a cool wet climate that is conducive to lichens and the development of lichen habitats, particularly in coastal forests (Clayden et al. 2011). Furthermore, Nova Scotia transcends the boundary between boreal and temperate forests, and therefore is colonized by lichen species either on the northern or southern limits of their geographic distribution (Davis and Browne 1996). Some examples include Boreal Felt Lichen, an endangered lichen at the southern extent of its range in North America and Vole Ears, an endangered lichen at the northern extent of its global range (Maass \& Yetman 2002, Cameron et al. 2011).

Many lichen species which are relatively common in Nova Scotia are rare and declining in the northeastern USA, and these are listed by Hinds \& Hinds (2007). Our province has a disproportionately high number of nationally listed lichen species. Nine of the of 24 lichen species listed by the Committee on the Status of Endangered Wildlife in Canada (COSEWIC) in Canada occur in Nova Scotia (COSEWIC 2019). Furthermore, roughly 10 percent of all the wildlife species listed provincially as At-Risk are lichens (Nova Scotia Department of Lands and Forestry 2019).

Like many other organisms, the distribution of lichens is neither random nor even across the landscape in Nova Scotia. Most of the at-risk, rare or uncommon lichens in NS occur in specific habitats in association with other at-risk lichen species in spatially discrete localities (Cameron \& Richardson 2006, Cameron \& Neily 2008, McMullin et al. 2008). Lichens such as the Boreal Felt Lichen, tend be clustered, with some clusters having high populations (Cameron \& Neily 2008, Cameron et al. 2013).

\footnotetext{
* Author to whom correspondence should be addressed: robert.cameron@novascotia.ca
} 
Given the diversity and number of rare lichens in the province, the Nova Scotia Lichen Recovery Team recognized the importance of identifying the specific areas with the highest lichen-richness. The intent was to identify these areas and direct efforts towards their conservation. Protection of these areas should ensure a more efficient conservation and protection of important lichen ecosystems, so helping to preserve the at-risk species.

A small team met in November 2016 and April 2017 to review lichen distribution data for Nova Scotia and identify Lichen-Rich Areas in the province. The team was aware that large parts of the province have not been searched for lichens. Thus this assessment reflects what has been achieved with the available data and using the personal knowledge of the team of expert lichenologists. We recognize that other Lichen-Rich Areas may occur which have not been as yet identified. Data sources used included the Atlantic Canada Conservation Data Centre (AC CDC), the Mersey Tobeatic Research Institute and the knowledge provided by expert lichenologists.

The initial approach was to develop and apply a set of criteria that captured the most significant Lichen-Rich Areas of the province. The following criteria were proposed and used to select the LichenRich Areas:

\section{Must have all of the following:}

1. Treed swamps, bogs, fens, riparian swamps and floodplains and their associated critical function zones as defined in the Voles Ears Recovery Strategy (Environment Canada 2014);

2. Historical continuity of forest cover as determined using historical satellite imagery, aerial photographs, forest cover Geographical Information System (GIS) data from Department of Lands and Forestry and field observations from lichenologists;

3. Low to zero anthropogenic disturbance prior to discovery of the site as revealed by a lack of human disturbance observed during field surveys;

\section{And two or more of the following features:}

4. Three or more records of lichen species that are rare, uncommon or At-Risk in Nova Scotia as defined by a status of S1, S2 or S3 by the AC CDC;

5. Three or more records of lichen species that are rare and declining elsewhere in Northeastern North America as indicated by Hinds 
\& Hinds (2007) such as Fuscopannaria leucosticta, Heterdermia leucomela and Pannaria lurida or Goward et al. (1999) such as Leptogium corticola, Letogium subtile and Everniatsrum catawbeinse;

6. Two or more thalli of a species listed as Endangered or Threatened under provincial or federal legislation.

\section{Lichen Concentration Area Boundaries}

Recent research on Boreal Felt Lichen indicates forestry and other activities within 500m can be a factor in mortality (Cameron et al. 2013). This $500 \mathrm{~m}$ zone of influence is reflected in the Special Management Practices for Crown Land adopted by the Nova Scotia Department of Lands and Forestry (2018) and recommended by the Nova Scotia Lichen Recovery Team. For sites where the Boreal Felt Lichen has been found, the boundaries were set to a $500 \mathrm{~m}$ radius zone. For all other species which are known to be sensitive to disturbance but for which less research exists, a $200 \mathrm{~m}$ radius boundary was adopted.

\section{RESULTS AND CONCLUSIONS}

Twenty-five Lichen-Rich Areas were identified and mapped using GIS. These Areas occur in 8 counties in NS (Fig 1). The total area for the 25 was calculated as 5482 ha. Most Lichen-Rich Areas lie along the Atlantic Coast from Shelburne to Cape Breton County although one Area was identified in Digby County and another in Cumberland County. Shelburne County had more Lichen-Rich Areas than any other county with nine being identified in this county alone. Although all Areas have remarkably rich lichen floras, one Area in Shelburne County is exceptional as it contained Leptogium hibernicum, which is extremely rare in North America, and the Endangered Boreal Felt Lichen and Endangered Vole Ears in addition to several other At-Risk lichens. The Richmond County Areas were notable for the high populations of Boreal Felt Lichen while an area in Digby County contained the only occurrence of Heterodermia leucomela in the province in addition to L. hiburnicum and many other At-Risk lichens.

The Lichen-Rich Areas identified in this study require extremely careful management and conservation. Clear-cutting in or near these areas must be avoided if we are to retain these Lichen-Rich Areas. We recommend that these Areas be left undisturbed by human activity. 


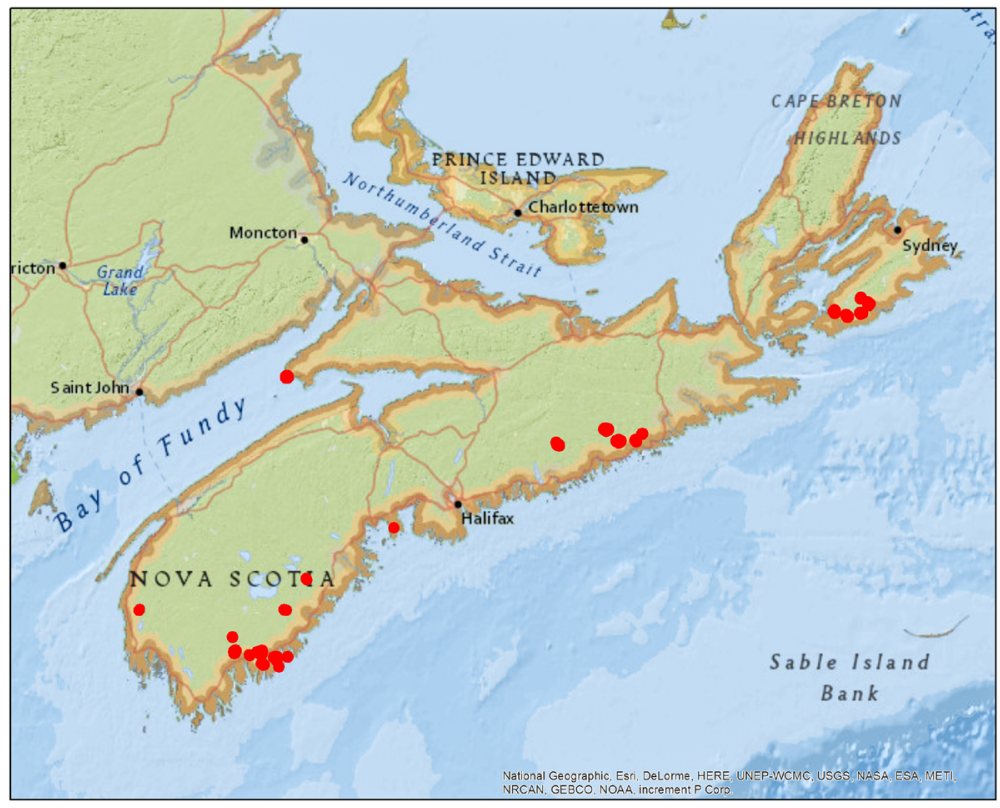

Fig 1 Approximate locations of twenty-five Lichen-rich Areas identified by lichenologists in Nova Scotia, using six criteria.

\section{REFERENCES}

Cameron, R.P. \& Neily, T. (2008). Heuristic model for predicting habitat of Erioderma pedicellatum and other rare cyanlichens in Nova Scotia, Canada. The Bryologist 111: 650-658.

Cameron, R.P., Neily, T. \& Clapp, H. (2013). Forest harvesting impacts on mortality of an endangered lichen at the landscape and stand scales. Canadian Journal of Forest Research 43: 507-511.

Cameron, R.P., Neily, T. \&. Clayden, S.R. (2011). Distribution model for Erioderma mollissimum in Atlantic Canada. The Bryologist 114: 231-238.

Cameron, R.P. \& Richardson, D.H.S. (2006). Occurrence and abundance of epiphytic cyanolichens in protected areas in Nova Scotia. Opuscula Philolichenum 3: 5-14.

Clayden, S.R., Cameron, R.P. \& McCarthy, J.W. (2011). Chapter 4 - Perhumid Coastal and Montane Forests of Eastern Canada. In D. DellaSalla (ed.) Temperate and Boreal Rain Forests of the World. Island Press, Washington, Covelo, London.

COSEWIC. (2019). Committee on the Status of Wildlife in Canada. Online at http://cosewic.ca/index.php/en-ca/ [accessed on 26 November 2019].

Davis, D. \& Browne, S. (1996). Natural History of Nova Scotia. 2 Vol. Nimbus Publishing and Nova Scotia Museum of Natural History, Halifax, NS. 
Environment Canada. (2014). Recovery Strategy for the Vole Ears Lichen (Erioderma mollissimum) in Canada. Species at Risk Act Recovery Strategy Series. Environment Canada, Ottawa. v +31 pp.

Goward, T., Brodo, I.M. \& Clayden, S.R. (1998). Rare Lichens of Canada: A Review and Provisional Listing. Committee on the Status of Endangered Wildlife in Canada, Ottawa.

Hinds, J.W. \& Hinds, P.L. (2007). The Macrolichens of New England. Memoirs of The New York Botanical Garden.

Maass, W.G.S. \& Yetman, D. (2002). COSEWIC Assessment and Status Report on the Boreal Felt Lichen (Erioderma pedicellatum) in Canada. Committee on the Status of Endangered Wildlife in Canada, Ottawa.

McMullin, R.T., Duinker, P.N., Cameron, R.P., Richardson, D.H.S. \& Brodo, I.M. (2008). Lichens of coniferous old-growth forests of southwestern Nova Scotia, Canada; diversity and present status. The Bryologist 111: 620-637.

Nova Scotia Department of Lands and Forestry. (2018). At-Risk LichensSpecial Management Practices online at https://novascotia.ca/natr/ wildlife/habitats/terrestrial/pdf/SMP_BFL_At-Risk-Lichens.pdf [accessed 26 November 2019].

Nova Scotia Department of Lands and Forestry. (2019). Species at Risk. Online at https://novascotia.ca/natr/wildlife/biodiversity/species-list.asp [accessed 26 November 2019]. 
